\title{
Locarno 2003
}

\author{
By Gönül Dönmez-Colin
}

Fall 2003 Issue of KINEMA

\section{THE $56^{\text {th }}$ LOCARNO INTERNATIONAL FILM FESTIVAL'S}

competition section (6-16 August, 2003) offered nineteen films mostly representing Europe except for two from Latin America, one from the US and five films from Asia representing five different countries. The overriding theme of the festival seemed to be human rights. Solitude across generations was the most explored subject.

Masahiro Kobayashi's Onna Riha Tsushi No Koi (The Hairdresser) was in some ways an extension of Japanese films of passion and obsession in the tradition of Oshima among others. The interesting part was that the woman who was abducted by her secret admirer gave in so easily, which magnified the sad solitude of her routine life with her obsessive gambler husband. The fact that the camera deliberately avoided to accentuate the passion, which was already overflowing was another plus to this film that impressed the audience with its composition, framing and tempo but perplexed with its ambiguous message.

Nariman Turebayev from Kazakhstan where the film industry hardly exists, except for co-productions, drew attention recently with his short films Romantika (2000) and Antiromantika (2001). His first feature, Malen'kie Ljudi (Little Man) is about dreams and disappointments of youth during adjustment to market economy. Beck and Max are army buddies with different temperaments who try to earn their living selling small items on the streets. Max is the extrovert. He believes in male conquest, in business and in sex. Beck, on the other hand is a shy young man who pursues his romantic ideal. Through various little episodes, the film leads to the conclusion that the new society created after independence in Central Asia is far ahead of individuals like Max and Beck, or totally in a different place. A beautiful film to watch, except for one aspect, which is rather troublesome. One does not know why all young and beautiful women, without exception, are shown as always willing to jump into bed with any stranger. The fantasies of a male director perhaps!

Alireza Amini who is considered by many as the leading voice of young generation filmmakers from Iran presented two films in Locarno, one of them in competition. His first film, Nameha ye Baad (Letters in the Wind) was shown in the Cineastes du Present (Filmmakers of the Present) section and Daneha ye Rize Barf (Tiny Snowflakes) in competition. In totally different styles and revolving around different subjects, these two films are very much interconnected. In the first film, young recruits in army barracks dream of the outside world and especially women and through female conversations recorded on a tape, they live their fantasies. The second film is set in an isolated mine, another male space just like the barracks. Two men who are marooned where it is dark most of the time find a ray of sunshine through the image of a woman who passes by in the distance. Unlike the first film that connects confined spaces through an audio medium, the second uses visual, both of which, incidentally are aspects of cinema. Hence, one can read into this film several tropes from allusions to the isolation of the country, which is deeply felt especially by the young generation in recent years, to restrictions of expression in art.

A favourite among film critics was South Korean Kim Ki-duk's Bom, Yeoreum, Gaeul, Gyeowool, Geurigo, Bom (Spring, Summer, Fall, Winter... and Spring), an allegory on life rendered with stunning visual images. The thrust of the film is the seasons of life, from innocence of childhood to self-centred maturity to selfless old age. Men and his connection with and reaction to nature are explored in the spirit of Zen Buddhism.

First feature of Sabiha Sumar from Pakistan, known for her documentaries on the plight of women in her country, Khamosh Pani (Silent Water) addressed a pressing issue, the rise of fundamentalism. The film takes place in 1979 when the martial law imposed by General Zia-ul-Haq and the rise of fundamentalism begins to spread intolerance through the country. Salim is an intelligent young man although somewhat misguided. He lives with his widowed mother and takes delight in flirting with his progressive minded girlfriend. When fundamentalists arrive in the village to recruit young men, with his dreams of enlarging his horizons, he becomes a good candidate. In the meanwhile, pilgrimage to an important Sikh shrine is 
authorised by the government resulting in many Sikhs arriving in the village. One of them is looking for his sister who was abducted during partition. Several scenes in sepia reveal atrocities of the time when both sides abducted/raped women of the other faith. Many families forced their daughters to suicide or pushed them into the wells to preserve the family honour. Some abducted women later married their abductors and settled in the foreign land. Salim is to find that his mother Ayesha is actually Veero, her secret being buried for so many years in a few photographs she kept locked in her trunk. Salim's fear and anger push him to extremes and he leads the fundamentalist mob who march to throw the Sikh pilgrims out of the village.

Sumar's rendition of the story is delicate. She does not create a victim in the character of Veero but instead builds a woman who comes to terms with her fate. Even her final suicide is not an act of weakness but rather liberation and a strong message to intolerance. The abduction scenes are skilfully choreographed leaving no room for commercial sensationalism. The weakness of the film is that the characters remain representatives of what they are meant to be rather than coming alive as flesh and blood.

Among the European entries in competition Les marins perdus (Lost Sailors) by Claire Devers from France drew attention firstly by the fact that one of the female leads, Marie Trintignant was recently murdered by her rock-star lover. Adapted from the eponymous novel of Jean-Claude Izzo, the film weaves together personal stories of several sailors who no longer have a ship. By some perverse logic, all bad characters happen to be Muslims. Abdul Aziz, the Lebanese captain is a rapist and a murderer. Nedim, the young Turk is also a rapist and a perfect fool. Furthermore, he likes to chant prayers from Koran as he masturbates. Arab women are shown as hustlers; their men as pimps and mobsters. The good guy is Diamantis, the Greek chief officer.

In the Cineastes du Present section, South Korean Gina Kim's first feature Geu Jip (Invisible Light) drew attention with its original narrative and presentation. The film has two female protagonists whose lives are interlinked through a man who is lover to one and husband to other, but it is not about a ménage-à-trois. The first woman lives in the US and she has just come to the end of a love affair with a married woman. She finds temporary solitude in controlling her eating habits and finally plunging into anorexia. The second woman returns to Seoul after a long absence. She is pregnant from a man other than her husband and has to make a decision. Both films explore women's relationship to their bodies and connect this with a search of identity, which results in the fusion of these two different characters.

The theme of jazz added a special atmosphere to the balmy nights of Locarno this year with a rich program of jazz films (old and new, fiction and documentary) and several concerts in the bars along the lake. But the real attraction was once again the outdoor screenings at the Piazza Grande, where a tongue-in-cheek musical of sixties nostalgia with Charles Busch as the ageing eccentric singer Angela Arden was a smash hit.

\section{References}

\section{AWARDS}

\section{Golden Leopard}

Khamosh Pani (Silent Water) by Sabiha Sumar (Pakistan-France-Germany)

Silver Leopard (The second best film):

Gori Vatra (Au feu) by Pjer Zalica (Bosnia-Herzegovina-Austria)

Silver Leopard for the best first or second feature

Thirteen by Catherine Hardwicke (USA)

\section{Special Jury Prize}

Maria by Calin Netzer (Romania-Germany-France)

\section{Leopard for the best actress}

Holly Hunter for the film Thirteen

Diana Dumbrava for the film Maria

Kirron Kher for the film Khomosh Pani 


\section{Special Mention}

Onna Rihatsushi no koi by Masahiro Kobayashi (Japan)

Danehaye Rize Barf by Alireza Amini (Iran; also Junior jury Special Prize)

FIPRESCI Prize

Dependencia Sexual (Sexual dependence) by Rodrigo Bellott (Bolivia-USA)

\section{Ecumenical Jury}

Khamosh Pani (Silent Waters)

NETPAC Jury

Bom, Yeoreum, Gaeul, Gyeowoll, Geurigo, Bom by Kim Ki-Duk (Korea-Germany)

\section{Author Information}

Gönül DÖNMEZ-COLIN is an independent researcher and writer whose publications include Women, Islam and Cinema, Cinemas of the Other: A personal Journey with Filmmakers from the Middle East and Central Asia, Cinema of North Africa and the Middle East (ed.); Turkish Cinema: Identity, Distance and Belonging (Reaktion Books), and Routledge Dictionary of Turkish Cinema (2014). 